\title{
ПРАВО НА ОХРАНУ ЗДОРОВЬЯ И МЕДИЦИНСКУЮ ПОМОЩЬ В РОССИЙСКОЙ ФЕДЕРАЦИИ КАК КОНСТИТУЦИОННАЯ ЦЕННОСТЬ
}

\begin{abstract}
Аннотация: В данной статье автор обосновывает аксиологическое значение права на охрану здоровья и медицинскую помощь его комплексным характером, так как оно связано с правом на жизнь, на благоприятную окружаюшую среду и другими. Кроме того изенностный характер указанного права заключается не только в защите такого неотчуждаемого блага, как здоровье, но и в создании условий для осуществления базовых прав на свободное развитие и достойную жизнь. Проведение мероприятий и программ по сохранению и восстановлению индивидуального и общественного здоровья являются одновременно обязательствами государства и личности. С целью обоснования и детализаџии аксиологического характера конституционного права на охрану здоровья и медицинскую помощь в статье были использованы системный подход, общенаучные методы анализа и синтеза; применены сравнительно-правовой, формально-юридический, конкретноисторический методы. Научная новизна статьи состоит в рассмотрении ценностных аспектов указанного права, которые в юридчческой науке проанализированы недостаточно, с позиции современных исследований и актуальных условий социальных преобразований. Данный ракурс изучения конституционного права на охрану здоровья и медицинскую помощь необходим для выявления новых закономерностей развития российского законодательства в указанной области.
\end{abstract}

Ключевые слова: Конституционное право, конституцчионная цุенность, правовая цченность, социиальная цุенность, государство, законодательство, достоинство личности, достойная жизнь, охрана здоровья, благо. Abstract: In this article the authors substantiate the axiological importance of the right to protection of health and medical aid by its complex nature, as it pertains to the right to life, favorable environment and others. In addition to that, the value nature of this right consists not only in the protection of such indefeasible benefit as health, but also in creation of conditions for exercising basic rights to free development and a worthy life. Campaigns and programs on protection and restoration of individual and public health are the obligations of both, the state and individual. The scientific novelty of this work consists in exploration of the value aspects of this right, which are not sufficiently analyzed within the juridical science, from the position of modern research and relevant conditions for social reforms. This approach towards the study of constitutional right to protection of health and medical aid is necessary in order to determine new regularities of development of the Russian legislation in this area.

Keywords: Ppersonal dignity, legislation, state, social value, legal value, consitiutional value, constitutional right, worthy life, health protection, welfare.

первые положение аксиологического характера появилось в Конституции РСФСР 1978 г.[1] (в редакции 1992 г.), статья 31 которой закрепила за правами, свободами, честью и достоинством личности статус высшей ценности. Преамбула действующей Конституции России 1993 г. констатирует такие базовые аксиологические аспекты, как утверждение прав и свобод человека и гражданина, сохранение столетиями складывавшегося единства российского государства, возрождение и неизменность демократической основы отечественной государственности; конституционными положениями фиксируются содержание и высший статус права на охрану здоровья и медицинскую помощь (ч. 1 ст. 41), как ценности, без которой могут оказаться несущественными многие блага, или последние вообще будут не достижимы.
Необходимо отметить плюрализм определений понятия «ценность», в которых последняя представлена в качестве предметов окружающего мира с определенной степенью значимости для человека; разновидности устойчивых мотивационных образований; [2, c.277] явления особой реальности, иррациональной по происхождению и существующей вне времени и пространства;[3] элемента общественных отношений. [4, с.25] В понятие ценность нередко включают различные аспекты психики человека,[5, с.7] стабильные собирательные представления и убеждения личности о нормах и целях собственных действий, отражающие исторический опыт и выражающие «смысл культуры отдельного этноса и всего человечества»,[6],[7, с.5] в связи с чем, можно вести речь о «социокультурных истоках ценностей».[8, с.124] В свою очередь, социально-экономическое развитие страны во многом 
определяется ценностями, преобладающими среди населения,[9, с. 22-23] которые, как правило, отражают «глубокие цивилизационные отличия».[10] Таким образом, и на специфичность государственноправовой традиции могут влиять ценности того или иного общества, опосредованные определенными социокультурными факторами, которые можно рассматривать в структуре «юридического архетипа», содержащего «первообразы и первонормы», концентрирующие политический, духовный, правовой опыт народа, фиксируемые в качестве когнитивных образцов восприятия правовых явлений, процессов и моделей поведения. [11, с.175]

Юристы выделяют «ценности права» и «ценности в праве». Посредством «ценностей в праве» (справедливость, равенство, демократия, порядок, безопасность, мир),[12] последнее позволяет реализовывать социально справедливые нужды и интересы человека и общества.[13, с.7-8] К «ценностям права» (или правовым ценностям) С.В. Михайлов[14] относит «обобщенные правовые цели и правовые средства их достижения, выполняющие роль правовых норм», которые желательны для достижения результатов социальных трансформаций в обществе, и в целом, необходимы для реализации социальных прав. Не случайно ценность правовых норм определяется актуальностью регулируемых ею отношений для общества,[15, с.140] и ценность права вообе связана с его оценкой, в качестве средства решения общественных задач.[16] В частности, «живучесть» правовой нормы опосредована моделью регулирования, которая обеспечивает защиту ценностей общества; $[17$, с. 136, 145] поддерживая и защищая наиболее общественно значимые из них.

В аксиологической экологии особую роль играют национальные конституции, «прямо» обозначающие ценности, уже облеченные в определенную правовую форму, которым в обязательном порядке должна следовать любая правовая конструкция.[18, с.66-67] Не является исключением действующий Основной закон Российской Федерации. При этом, часть конституционных ценностей выражена в нем явно (человек, его права и свободы), другая часть - обнаруживается в процессе толкования Конституции России (например, федерализм, разделение властей).[19, с.16]

Президент России к ценностям конституционного ранга относит жизнь человека, и его достоинство, благополучие и единство, демократию и законность, свободу и справедливость.[20],[21] С.А. Авакьян[22] включает в реестр ценностей государство, подчиненность конституционных норм интересам индивида, выборы; Г.Б. Ройзман[23] - безопасность государства и его обороноспособность, основы конституционного строя и права человека, нравственность и здоровье; Н.С. Бондарь[24] - категорию социальной справедливости, демократический правовой порядок. Самостоятельными ценностями считают публичную власть; принцип сочетания частных и публичных интересов; институт равенства прав и обязанностей.[25]

Е.В. Ереклинцева[26] отмечает, что благодаря конституционно-зафиксированным ценностям (в виде общезначимых социальных целей, принципов или установок) возможно достижение равновесного соотношения между ними и частно-публичными интересами с учетом принципа справедливости, который Конституционный Суд РФ в Постановлении от 02.07.2013 № 16-П[27] рекомендует учитывать при регламентации правоотношений в той или иной сфере. Для сохранения баланса между конституционными ценностями, законодатель должен обеспечивать правовое регулирование основных обязанностей государства (а также личности), путем определения их нормативного содержания, вариантов реализации, гарантий, предусматривая меру юридической ответственности за их нарушение.[28] Данное положение в полной мере относится к основным правам человека и гражданина, как к максимально достижимым аксиологическим ориентирам, которые позволяют индивиду занимать наиболее эффективное (с точки зрения реализации основных прав и свобод) положение в социально-ориентированном государстве. В связи с этим, своевременным представляется аксиологический анализ конституционных прав, который можно представить на примере права на охрану здоровья и медицинскую помощь.

Прежде всего, ценностная структура данного права обусловлена значимыми социальным и институциональным элементами в его составе, так как потребности индивидов в сфере охраны здоровья удовлетворяются не столько самостоятельно, сколько при участии организаций различных систем здравоохранения (государственной, частной, муниципальной). Ю.А. Тихомиров[29] подчеркивает, что в практике последних десятилетий охрана здоровья граждан рассматривалась как целенаправленная деятельность, в первую очередь, государства в лице его различных органов и учреждений. И.А. Колоцей[30, с.10] отмечает, что право на охрану здоровья и медицинскую помощь должно быть гарантировано «правовыми финансовыми и организационными ресурсами государства и общества». А.Е. Черных[31] также отстаивает невозможность развития охраны здоровья «без законодательного обеспечения государственных гарантий, в том числе доступности и качества медицинской помощи». 
Поэтому на законодательном уровне закреплена необходимость государственного контроля качества в сфере охраны здоровья, установлен объем бюджетного финансирования данной сферы; государственные и общественные институты поощряют мероприятия по развитию физической культуры и спорта, поддержанию экологического и санитарно-эпидемиологического благополучия, что, в целом, способствует укреплению здоровья индивидов. Следовательно, соглашаясь с точкой зрения Г.В. Балашовой[32] и В.В. Власенковой[33], которые подчеркивают, что охрана здоровья граждан выступает важным направлением деятельности государства, можно считать, что конституционное право на охрану здоровья и медицинскую помощь служит одним из ориентиров в проведении государством социальной политики,[34] что повышает аксиологическую значимость указанного права.

С целью реализации конституционных социально-экономических прав государство берет обязательства совершать ряд организационно-правовых мероприятий (принимать законы и подзаконные акты, организовывать определенные службы),[35] то есть, выполняет конституционно зафиксированную обязанность по укреплению и охране здоровья населения, по созданию условий для максимально полной реализации права на охрану здоровья и медицинскую помощь. В частности, исторический опыт России свидетельствует о том, что прямое законодательное и конституционное закрепление права на охрану здоровья стало возможным только в 60-70-е годы прошлого столетия, после того, как была сформирована система здравоохранения в стране. Это вряд ли было бы осуществимо без участия государства, в распоряжении которого - целый набор продуктивных инструментов, от обязательной высшей силы нормативных актов государства в иерархии правовых документов, - до системы органов, способных защищать права и свободы, предотвращать посягательства на них, привлекать к ответственности за их нарушения.[36]

В.И. Крусс[37, с.35] объясняет особое аксиологическое значение конституционных ценностей тем фактом, что они абсолютны, объективны (как «средство социокультурного самосохранения народа в условиях глобализации»), конституционно правомерны, подразумевают реализацию прав и свобод человека, а также нормативны. Нормативность права на охрану здоровья и медицинскую помощь выражается в регулятивном воздействии указанного права, ценностном контексте содержащихся в нем правомочий, в определенности юридических гарантий.[38] Указанные параметры определяют основные направления законодательной регламентации сферы охраны здоровья.
М.С. Пермиловский[39] полагает, что правила поведения можно перемещать в категорию конституционной ценности на основании таких критериев, как: максимальная польза, аксиологический ориентир и абсолютность нормы. Если вести речь о праве на охрану здоровья и медицинскую помощь, то факт абсолютности нормы, закрепляющей его, следует из императивной фиксации прав человека в качестве ценности наивысшего порядка. Максимальная польза права на охрану здоровья и медицинскую помощь и его ценностный аспект вытекают из тесной взаимосвязи указанного права с иными правами, также обладающими высшим аксиологическим смыслом, в частности, с правом на жизнь, личное достоинство, с правом добывать собственным трудом материальные средства. В свою очередь, состояние здоровья напрямую зависит от благополучных санитарно-эпидемиологических и экологических условий, отсутствия пыток, насилия, иных жестоких вариантов обращения или наказания; от условий безопасности и гигиены на рабочем месте; от оптимального социального обеспечения. Таким образом, аксиологический характер конституционного права на охрану здоровья и медицинскую помощь также обусловлен его комплексным характером, поскольку оно прочно связано с иными ценностями (правом на жизнь, на благоприятную окружающую среду и другими), как в силу факта их равно признанной конституционности, так и на основании эффекта взаимного влияния, причем как отрицательного, так и положительного. Например, оптимизация экологической ситуации в отдельно взятом регионе планеты может привести к улучшению показателей общественного и индивидуального здоровья в целом ряде стран. В то же время, нередко только после ухудшения состояния здоровья индивид может в полной мере осознать ценность жизни.

Следовательно, можно вести речь о взаимосвязи и взаимодействии прав и свобод, защищающих помимо здоровья, другие, не менее значимые, но связанные с ним блага. Неразрывно «спаянная» с иными ценностями комплексная аксиологическая природа права на охрану здоровья и медицинскую помощь подтверждает точку зрения Б.С. Эбзеева,[40, с. 173] согласно которой в настоящее время существует тенденция к универсализации и «системному единству взаимопроникающих и взаимодополняющих конституционных ценностей индивидуальной и социальной жизни», которые можно рассматривать в рамках «доктрины общего блага». Не случайно В.В. Чепурин[41] подчеркивает, что аксиологический подход к конституционному праву на охрану здоровья и медицинскую помощь человека, опосредован «высшей абсолютной 
ценностью защищаемого посредством него блага». Конституционный Суд России также рассматривает здоровье и жизнь человека в структуре общего блага,[42][43] без которых теряют смысл иные ценности. Следует согласиться и с И.А. Карасевой,[44] которая отмечает, что конституционные ценности - это по сути и есть блага, материализованные в разнообразных юридических формах (в целом, в нормах общего характера, нормах-принципах, правах и свободах), которые конституционно зафиксированы и выкристаллизовываются из содержания Основного закона в процессе официального толкования. Поэтому логична позиция Конституционного Суда России, который в Определении от 19.05.2009 № 816-О-О, с учетом п. 2 ст. 1083, а также ст. 1100 Гражданского кодекса Российской Федерации, подчеркивает, что в случаях нанесения вреда жизни и здоровью (то есть, нематериальным благам) гражданина, полный отказ от его возмещения невозможен, независимо от вины причинителя вреда.[45][46] Таким образом, закономерно считать «здоровье» неотчуждаемым благом, социальным явлением, фундаментальной и универсальной конституционной ценностью.[47]

Ю.Д. Сергеев и А.А. Мохов[48, с.14] рассматривают благосостояние общества через призму общего благополучия (то есть, здоровья) каждого отдельного человека. В то же время, здоровье индивидов, которое «интегрировано в здоровье нации», влияет на экономический прогресс, являясь одним из основных направлений в достижении национальной безопасности государства.[49, с.26]Кроме того, здоровье и безопасность государства находятся в одном ряду среди тех конституционных ценностей, для защиты которых возможно ограничение основных прав и свобод человека и гражданина (ч.3 ст. 55 Конституции России). Следовательно, здоровье представляет собой абсолютное благо, как личного, так и общественного порядка.

Аксиологическую значимость права на охрану здоровья и медицинскую помощь усиливает деятельность конституционных судов, которые «обогащают» ценности Основного закона дополнительным нормативным содержанием. Данная тенденция обусловлена, с одной стороны, противоречивостью, пробелами, неравномерностью развития социального законодательства;[50, с.49] с другой стороны - отражает процесс правовой глобализации, для которого характерно правовое нормирование основных сфер социальной жизни.[51, с.67] В частности, Конституционный Суд Российской Федерации в разные годы рекомендовал законодателю установить более детальные правила предоставления медицинской помощи с учетом специфики оказываемых услуг,[52] разработать адекватный организационно-правовой механизм ввоза лекарственных препаратов для лечения редких заболеваний, чтобы гарантировать доступ к ним со стороны соответствующих пациентов;[53] уточнить вопросы возмещения вреда здоровью, причиненного определенным субъектам (например, военнослужащим,[54] сотрудникам полиции[55]) в ходе профессиональной деятельности.

Помимо этого, аксиологическое значение права на охрану здоровья и медицинскую помощь также заключается в том, что его реализация способствует формированию благоприятных условий для осуществления базовых прав на свободное развитие и достойную жизнь (ч. 1 ст. 7 Конституции России). Принимая во внимание то обстоятельство, что понятие «достойная жизнь» включает определенный медицинский уход, необходимое социальное обслуживание, то есть, жизненный уровень, который первостепенен для поддержания здоровья индивида и его семьи (ст. 25 Всеобщей декларации прав человека 1948 г.[56]), то в данном контексте можно вести речь о «достойном уровне жизни», как о благе-ценности, тем более, что достойная жизнь немыслима без максимально достижимого уровня здоровья.

Необходимо отметить, что достоинство личности представляет собой один из ключевых способов оценки функционирования правового государства, и его уважение выполняет роль общего принципа, охватывающего в целом всю систему социального механизма действия права. В то же время, инновационные достижения биоэтики, повышение частоты инструментальных вмешательств в органическую природу человека (репродуктивные технологии, мероприятия с эмбрионами, эвтаназия и др.), заставляют задуматься об опасностях, компрометирующих ценность достоинства человека, так как существует угроза генных манипуляций, правонарушений при изъятии органов для трансплантации, что деформирует и деструктивно влияет на телесную и душевную целостность человека.[57]

В последние годы риск оказывается «постоянно действующим социальным фактором», и возникают предпосылки к переходу к обществу, в котором в качестве ценностей могут быть признаны именно риск и рискованный образ жизни. Не случайно В.В. Чепурин[58] предлагает ввести понятие «безопасной жизнедеятельности человека», актуальность которой возрастает на фоне «разрушительного влияния промышленности и окружающей среды». В частности, в Концепции долгосрочного социально-экономического развития Российской Федерации на период до 2020 года,[59] в Государственной программе «Развитие 
здравоохранения»,[60] законодатель формулирует необходимость решения задачи «по повышению эффективности человеческого капитала и созданию комфортных социальных условий» в «модели инновационного социально ориентированного развития».

При этом невозможно отрицать существование в настоящее время проблемы безопасности в сфере охраны здоровья. Агрессивное течение научно-технических инновационных процессов в медико-фармацевтическом секторе может отрицательно влиять на полноту осуществления права на неприкосновенность личности, на охрану чести и достоинства; на жизнь и на охрану здоровья. Поэтому, по-видимому, в ближайшие годы придется задуматься об обеспечении безопасности в сфере охраны здоровья, под которым следует понимать, прежде всего, процесс оказания индивиду организацией здравоохранения более безопасной медицинской помощи, снизив до приемлемого минимума риск нанесения вреда, вызванного ненадлежащим функционированием системы здравоохранения, применением инновационных продуктов и технологий, особенно у четом того факта, что в настоящее время можно вести речь существовании источников повышенной опасности в указанной сфере.[61] Закономерным представляется вывод В.Б. Устьянцевой[62, с.169], которая считает, что безопасность уже в настоящее время следует наделить статусом «общественно организованного потребительского блага».

В связи с этим, аксиологический анализ конституционного права на охрану здоровья и медицинскую помощь следует проводить на трех уровнях: индивидуальном, конституционно-правовом и на концептуальном. На первом уровне, данное право закрепляет и гарантирует право на охрану здоровья и медицинскую помощь, без которых человек (как высшая ценность) не может действовать инициативно и самостоятельно; удовлетворять потребности с учетом своей биологической и социальной роли. Указанное право имеет комплексный характер, и его адекватная реализация приводит к обретению индивидом иных конституционных ценностей (достойная жизнь, свободное развитие, достоинство, неприкосновенность), к осуществлению иных основных прав. На этом уровне реализация конституционного права на охрану здоровья во многом определяется отношением каждого человека к такой ценности, как здоровье, в индивидуальном аспекте.

К индивидуальными ценностям в целом целесообразно относить элементы личности человека, базирующиеся на совокупности его ресурсов (обусловленных особенностями его воспитания, образо- ванием, состоянием здоровья, жизненным опытом), а также отражающие общие установки определенного вектора индивидуального развития и исторического периода страны проживания, то есть обусловленные социокультурными (историческими, религиозными, этническими профессиональными, семейными и другими) факторами, которые влияют на выделение индивидом определенных доминирующих целей в субъективной и окружающей объективной реальности, что способствует возникновению у него в каждый конкретный момент мыслей, взглядов, оценочных суждений, приводящих к реализации наиболее значимых моделей поведения, и направленных на осуществление указанных целей. В связи с этим, ценность конституционного права на охрану здоровья и медицинскую помощь на индивидуальном уровне обусловлена, прежде всего, ценностно-ориентированным отношением к здоровью, которое может быть высоким и низким. В первом случае устойчивая установка индивида на здоровый образ жизни, на проведение мероприятий по сохранению и укреплению здоровья, позволяет поддерживать наиболее приемлемый уровень последнего и приводит к минимальной потребности в ресурсах государственной, муниципальной, частной систем здравоохранения в рамках реализации соответствующего конституционного права. При воздействии вредоносных обстоятельств, многих видов инфекций, онкологических заболеваний на индивидов с высокой ценностно-ориентированным отношением к здоровью, аксиологическая значимость соответствующего конституционного права возрастает и позволяет достигать индивидуальной безопасности в виде «сохранности и надежности жизни и здоровья человека»[63]. При низком ценностно-ориентированном отношении к здоровью аксиологическая значимость указанного права также невысока. Таким образом, на индивидуальном уровне, ценность конституционного права на охрану здоровья и медицинскую помощь во многом зависит от личного отношения индивида к такому защищаемому данным правом благу-ценности, как здоровье, и собственных действий человека в направлении его сохранения, поддержания и укрепления.

На втором уровне конституционное право на охрану здоровья и медицинскую помощь обусловлено тем обстоятельством, что здоровье представляет собой «средство институциализации общественной жизни»,[64] один из индексов социально-экономического благополучия; является ключевым условием воспроизводства населения в рамках реализации государственных программ демографического развития страны. Поэтому на этом (втором) уровне цен- 
ность конституционного права на охрану здоровья и медицинскую помощь в основном поддерживается усилиями государства и его органов. В частности, общественный статус здоровья придает смысл гарантии такой конституционной ценности, как медицинская помощь; является ключевым условием функционирования государства, которое осуществляет свою конституционную обязанность по соблюдению, признанию и обеспечению права на охрану здоровья и медицинскую помощь, проводя государственный контроль в медико-фармацевтическом секторе; мониторинг безопасности медицинской и фармацевтической деятельности. При решении неоднозначных вопросов в сфере охраны здоровья особая, мелиоративная роль отводится конституционному правосудию, правовые позиции которого имеют самостоятельное аксиологическое значение.

Кроме того, на втором уровне не следует забывать о нормативно-регулирующей функции права на охрану здоровья и медицинскую помощь, которая диктует необходимость законодательного закрепления ответственности, связанной с любыми посягательствами на здоровье, введение ограничений на реализацию основных прав человека и гражданина при угрозах здоровью и безопасности населения. Указанная функция также была бы невозможна без законодательной фиксации аксиологического статуса права на охрану здоровья и медицинскую помощь, поскольку шкала ценностей в любом обществе, отражая в целом «цивилизационный архетип», позволяет «разграничить правовое от неправового».[65, с.145] Кроме того, ценности, по мнению Л.О. Мурашко[66, с.14-15; 301-302], способствуют верификации эффективности правовой нормы путем оценки результативности модели регулирования, и обоснованному проведению конкретной социальной практики, в связи с чем, в ходе правообразования следует учитывать своеобразный функциональный круговорот ценности в обществе («ценностный круг»).

Таким образом, нормативно-регулирующая функция права на охрану здоровья и медицинскую помощь, с одной стороны, опосредована его ценностной каннотацией в конституционно-правовом материале; с другой стороны - законодательно признанный высший аксиологический статус указанного права позволяет защищать и реализовывать это право более эффективно. Не случайно А.А. Чесноков[67] уточняет, что исторически в России защита социально-экономических прав обретала реалистичные очертания за счет их позитивной фиксации в правовом материале, после которой индивид мог рассчитывать на их нормативную защиту.
Следовательно, законодательное признание аксиологической значимости конституционного права на охрану здоровья и медицинскую помощь - это основание для проведения нормативно-регулирующих мероприятий с целью: 1) создания эффективной юридической платформы для реализации данного права, его протекции, проведению деятельности по профилактике нарушений и установлению пределов ответственности при любых посягательствах; 2) введения ограничений на осуществление иных основных прав и свобод человека и гражданина в случае угроз здоровью и безопасности населения; 3) диагностики основных тенденций развития законодательства в сфере охраны здоровья.

На третьем, концептуальном уровне аксиологическая значимость конституционного права на охрану здоровья и медицинскую помощь опосредована универсальностью, абсолютностью и общественным характером того блага (здоровье), которое защищает данное право. Если учесть, что здоровье представляет собой безусловный базис для всестороннего развития каждого конкретного индивида, и своеобразный «допуск» к осуществлению мер, направленных на достижение наиболее оптимального уровня жизни, то данное право составляет основу экономического роста и благополучия нации; выполняет приоритетную роль в процессе разработки:

1. концепций: социально-экономического развития[68]; демографической политики[69]; политики, направленной на снижение потребления табака[70]

2. доктрин: развития российской науки[71];

3. стратегий: лекарственного обеспечения[72], инновационного развития[73]; развития медицинской науки[74] и информационного общества[75]; по проведению действий в интересах детей[76] и по антинаркотической политике[77];

4. государственных и федерально-целевых программ: в области здравоохранения[78]; по созданию «Информационного общества»,[79] по развитию медико-фармацевтического промышленного сектора.[80]

По мнению Б.С. Эбзеева[81, с. 110] в России признаются не только экономические, социальные и культурные права, но и право на безопасность в различных сферах. Если учесть, что право на безопасность личности рассматривают в качестве социально-правовой и конституционно-правовой ценности,[82, с.16-17] то аксиологический потенциал права на охрану здоровья и медицинскую помощь также усиливает тот факт, что, реализация указанного права, которая подразумевает достижение приемлемого уровня здоровья- 
благополучия-блага каждого конкретного индивида, неразрывно связана с обеспечением безопасности личной, общественной, национальной.

Данный вывод подтверждает ряд правовых документов концептуально-доктринального, стратегического и программного характера, в основе которых - здоровье населения при условии поддержания продовольственной[83], информационной[84], общественной[85], химической и биологической[86] безопасности.

Аксиологическую значимость конституционного права на охрану здоровья повышает его высокий гуманистический потенциал, обусловленный социальным характером данного права, которое предоставляет гарантированный доступ к абсолютному благу-ценности (здоровью) для наиболее уязвимых социальных групп, нуждающихся в форсированной поддержке со стороны государства, что по сути «льет воду» на достижение условий, когда возможно вести речь о социальной безопасности, содержание которой заключается не только в защите, но и в «социальном служении, развитии общества, создании наилучших условий для жизнедеятельности человека»,[87, с.8,93] в устойчивой, благоприятной эволюции законодательного регулирования сферы охраны здоровья. Курс на оптимальную модель общественного здоровья («здоровье при высоком качестве жизни людей»),[88] закономерно должен способствовать достижению индивидуальной, общественной и национальной безопасности.

\section{Библиография:}

1. Авакьян С.А. Глобализация, общие конституционные ценности и национальное регулирование // Социальные интересы. 2001. № 4. С. 44-47.

2. Ардашев А.И. Конституционные основы обеспечения безопасности личности в Российской Федерации: Автореферат дис...канд. юрид. наук. Москва, 2008. С. 16-17.

3. Баева Л.В. Ценностные основания индивидуального бытия: Опыт экзистенциальной аксиологии: Монография. М.: Прометей. МПГУ, 2003. 240 с. С. 7-8.

4. Балашова Г.В. Право на охрану здоровья и медицинскую помощь в Российской Федерации: дис. ... канд. юрид. наук. Москва, 2000. С. 147.

5. Бевеликова Н.М. Конституционно-правовые основы компетенции органов публичной власти в сфере здравоохранения: дис. ... канд. юрид. наук. Москва, 2010. С. 25.

6. Богомолов А.С. Опредмечивание, ценности и социологическое познание // Социологические исследования. 1975. № 2. C. 54-61.

7. Бондарь Н.С. Аксиология судебного конституционализма: конституционные ценности в теории и практике конституционного правосудия. Серия «Библиотечка судебного конституционализма». Вып. 2. - М.: Юрист, 2013. С. 164.

8. Власенкова В.В. Право на охрану здоровья и медицинскую помощь в Российской Федерации: Автореферат дис. ... канд. юрид. наук. Москва, 2007. 21 с.

9. Власова О. В. Достоинство человека как нравственно-правовая ценность : общетеоретическое исследование: Автореф. дис. ... докт. юрид. наук. Саратов, 2011.

10. Всеобщая декларация прав человека. Принята резолюцией 217 А (III) Генеральной Ассамблеи ООН от 10 декабря 1948 года. http://www.un.org/ru/documents/decl_conv/declarations/declhr

11. «Гражданский кодекс Российской Федерации» от 30.11.1994 N 51-Ф3 // Собрание законодательства РФ. 1994 . № 32. Ст. 3301.

12. «Доктрина информационной безопасности Российской Федерации» (утв. Президентом РФ 09.09.2000 N Пр-1895) // Российская газета. 2000. № 187.

13. Домникова Л.В. Гражданско-правовые способы реализации права на охрану здоровья в Российской Федерации: дис.... канд. юрид.наук. Москва, 2006. 183 с.

14. Ереклинцева Е.В. Суверенитет и демократия как конституционные ценности современной России: Автореферат дис. ... канд. юрид. наук. Челябинск, 2010. 25 с.

15. Зорькин В.Д. Социальное государство в России: проблемы реализации // Сравнительное конституционное обозрение. 2008. № 1(62). С. 49.

16. Казанцева О.Л. Конституционные ценности: современный опыт России и зарубежных стран: монография / О.Л. Казанцева, Ю.А. Рудт, М.Н. Воробьева; науч. ред. Е.С. Аничкин. - Барнаул: изд-во Алт. ун-та, 2013. 137 c. (C. 16).

17. Каменская Н.А. Проблемы формирования общих принципов реализации конституционного права на охрану здоровья и медицинскую помощь в Российской Федерации // Медицинское право. 2011. № 4 (38). С. 20-24.

18. Карасева И.А. Конкуренция конституционных ценностей в практике Конституционного Суда Российской Федерации и Конституционных Судов зарубежных стран: дис. ... канд. юрид. наук. Москва, 2014. 244 с.

19. Колоцей И.А. Право на охрану здоровья и медицинскую помощь как конституционная ценность: Автореферат дис. ... канд. юрид. наук. Санкт-Петербург. 2010. 21 с.

20. «Конституция (Основной Закон) Российской Федерации - России» (принята ВС РСФСР 12.04.1978) // Ведомости ВС РСФСР. 1978. № 15. Ст. 407. 
21. «Концепция общественной безопасности в Российской Федерации» (утв. Президентом РФ14.11.2013 N Пр-2685) // Справочно-правовая Система КонсультантПлюс

22. Крусс В. И. Здоровье как основная правовая ценность современности // Проблемы права. 2012. № 4 (35). С. 21-40.

23. Лапин Н.И. Модернизация базовых ценностей россиян // Социологические исследования. 1996. № 5. С.3-23.

24. Ларионова И.С. Здоровье как социальная ценность: дис. ... докт. филос. наук. Москва, 2004. 265 с.

25. Леонтьев Д.А. Психология смысла: природа, строение и динамика смысловой реальности / Д.А. Леонтьев. - М.: Смысл, 2003. 487 с.

26. Литовкина М.И. Источники повышенной опасности в сфере охраны здоровья: конституционно-правовой формат проблемы // Национальная безопасность / nota bene. 2014. № 4. С.584-606

27. Мамут Л.С. Государство в ценностном измерении. - М.: Издательство НОРМА, 1998. 48 с.

28. Мастикова Н.С. Ценностный аспект процесса модернизации: сравнение ценностей россиян и европейцев: Автореферат дис ... канд. социол. наук. Москва, 2015. 170 с.

29. Михайлов С. В. Правовые ценности: теоретико-правовой аспект: дис.... канд. юрид. наук. Ростов-на-Дону, 2011. 200 с.

30. Мурашко Л. О. Аксиологическое измерение процесса правообразования: история и современность: дис.... докт. юрид. наук. Москва, 2015. 378 с.

31. Неновски Н. Право и ценности. - М., Прогресс. 1987. С. 177.

32. Общество риска и человек. Онтологический и ценностный аспекты. Под редакцией д. ф. н., проф. В.Б. Устьянцева Саратов: ООО Издательский центр «Наука», 2006. 289 с.

33. Определение Конституционного Суда РФ от 06.06.2002 № 115-О «Об отказе в принятии к рассмотрению жалобы гражданки Мартыновой Евгении Захаровны на нарушение ее конституционных прав пунктом 2 статьи 779 и пунктом 2 статьи 782 Гражданского кодекса Российской Федерации» // Вестник Конституционного Суда РФ. 2003 . № 1.

34. Определение Конституционного Суда РФ от 03.07.2008 № 676-О-П «По жалобе гражданина Радзиевского Бориса Владимировича на нарушение его конституционных прав положениями Федерального закона «О лекарственных средствах» // Собрание законодательства РФ. 2009. № 5. Ст. 676.

35. Определение Конституционного Суда РФ от 19.05.2009 № 816-О-О «Об отказе в принятии к рассмотрению жалобы гражданина Шевченко Андрея Александровича на нарушение его конституционных прав абзацем вторым пункта 2 статьи 1083 и абзацем вторым статьи 1100 Гражданского кодекса Российской Федерации» // Собрание законодательства РФ. 2009. № 42. Ст. 4970.

36. Определение Конституционного Суда РФ от 04.02.2014 № 373-О «Об отказе в принятии к рассмотрению жалобы гражданки Шарафутдиновой Лейсан Ирековны на нарушение ее конституционных прав положениями части 2 статьи 71 Федерального закона «Об обращении лекарственных средств» и части 3.3 статьи 34 Федерального закона «О размещении заказов на поставки товаров, выполнение работ, оказание услуг для государственных и муниципальных нужд» // Информационно-справочная система «Консультант-Плюс».

37. Осипова М.В. Иерархия юридических ценностей в правовой системе Российской Федерации: дис ... канд. юрид. наук. Саратов, 2011. 200 c.

38. «Основы государственной политики в области обеспечения химической и биологической безопасности Российской Федерации на период до 2025 года и дальнейшую перспективу» (утв. Президентом РФ 01.11.2013 №Пр-2573) // Справочно-правовая Система КонсультантПлюс

39. Пермиловский М.С. Право на благоприятную окружающую среду как конституционная ценность: Автореферат дис. ... канд. юрид. наук. Казань, 2014. 33 с.

40. Поляков А.В. Общая теория права: проблемы интерпретации в контексте коммуникативного подхода: учебник / А.В. Поляков. - СПб.: С. - Петерб. гос. ун-т, 2004. 260 с.

41. Послание Президента РФ В.В. Путина Федеральному Собранию РФ от 25 апреля 2005 г. // Российская газета. 2005 . № 86.

42. Послание Президента РФ Федеральному Собранию от 05.11.2008 «Послание Президента РФ Федеральному Собранию» // Российская газета. 2008. № 230.

43. Постановление Правительства РФ от 17.02.2011 N 91 «О федеральной целевой программе «Развитие фармацевтической и медицинской промышленности Российской Федерации на период до 2020 года и дальнейшую перспективу» // Собрание законодательства РФ. 2011. № 12. Ст. 1628.

44. Постановление Правительства РФ от 15.04.2014 N 313 «Об утверждении государственной программы Российской Федерации «Информационное общество (2011-2020 годы)» // Собрание законодательства РФ. 2014 . № 18 (часть II). Ст. 2159.

45. Постановление Конституционного Суда РФ от 31.05.2005 N 6-П «По делу о проверке конституционности Федерального закона «Об обязательном страховании гражданской ответственности владельцев транспортных средств» в связи с запросами Государственного Собрания-Эл Курултай Республики Алтай, Волгоградской областной Думы, группы депутатов Государственной Думы и жалобой гражданина С.Н. Шевцова» // Информационно-справочная система «Консультант-Плюс».

46. Постановление Конституционного Суда РФ от 14.05.2009 № 8-П «По делу о проверке конституционности положения подпункта «б» пункта 4 Постановления Правительства Российской Федерации «Об утверждении Порядка определения платы и ее предельных размеров за загрязнение окружающей природной среды, размещение отходов, другие виды вредного воздействия» в связи с запросом Верховного суда Республики Татарстан» // Собрание законодательства РФ. 2009. № 22. Ст. 2752.

47. Постановление Конституционного Суда РФ от 20.10.2010 N 18-П «По делу о проверке конституционности ряда положений статьи 18 Федерального закона «О статусе военнослужащих» и статьи 1084 Гражданского кодекса Российской 


\section{Государственные институты и правовые системы}

Федерации в связи с запросом Ногайского районного суда Республики Дагестан» // Вестник Конституционного Суда РФ. 2010. № 6.

48. Постановление Конституционного Суда РФ от 27.03.2012 N 7-П «По делу о проверке конституционности положений части второй статьи 29 Закона Российской Федерации «О милиции» и пункта 1 части 3 статьи 43 Федерального закона «О полиции» в связи с запросом Железнодорожного районного суда города Пензы» // Вестник Конституционного Суда РФ. 2012. № 3.

49. Постановление Конституционного Суда РФ от 02.07.2013 № 16-П «По делу о проверке конституционности положений части первой статьи 237 Уголовно-процессуального кодекса Российской Федерации в связи с жалобой гражданина Республики Узбекистан Б.Т. Гадаева и запросом Курганского областного суда» // Собрание законодательства РФ. 2013. № 28. Ст. 3881.

50. Приказ Минздрава России от 13.02.2013 № 66 «Об утверждении Стратегии лекарственного обеспечения населения Российской Федерации на период до 2025 года и плана ее реализации» // Ваше право. 2013. № 8.

51. Распоряжение Правительства РФ от 17.11.2008 № 1662-р «О Концепции долгосрочного социально-экономического развития Российской Федерации на период до 2020 года» // Собрание законодательства РФ. 2008. № 47. Ст. 5489.

52. Распоряжение Правительства РФ от 23.09.2010 N 1563-р «О Концепции осуществления государственной политики противодействия потреблению табака на 2010-2015 годы» // Собрание законодательства РФ. 2010. № 40. Ст. 5118.

53. Распоряжение Правительства РФ от 08.12.2011 № 2227-р «Об утверждении Стратегии инновационного развития Российской Федерации на период до 2020 года» // Собрание законодательства РФ. 2012. № 1. Ст. 216.

54. Распоряжение Правительства РФ от 28.12.2012 № 2580-р «Об утверждении Стратегии развития медицинской науки в Российской Федерации на период до 2025 года» // Собрание законодательства РФ. 14.01.2013. № 2. Ст. 111.

55. Распоряжение Правительства РФ от 15.04.2014 № 294 «Об утверждении государственной программы Российской Федерации «Развитие здравоохранения» // Собрание законодательства РФ. 2014. № 17. Ст. 2057.

56. Ройзман Г.Б. Понятие и юридическая природа конституционных ценностей // Вестник Челябинского государственного университета. 2012. № 1 (255). Право. Вып. 31. С. 18-24.

57. Сергеев Ю.Д., Мохов А.А. Ненадлежащее врачевание: возмещение вреда здоровью и жизни пациента. - М.: ГЭОТАРМедиа. 2007.

58. Снежко О.А. Конституционные основы государственной защиты прав и свобод человека и гражданина в Российской Федерации: дис. ... канд. юрид. наук. Саратов, 1999. 192 с.

59. Социальное законодательство: научно-практическое пособие / под. ред. Ю.А. Тихомирова, В.Н. Зенкова. - М.: Ин-т сравнительного правоведения при Правительстве Рос. Федерации, 2005.

60. «Стратегия развития информационного общества в Российской Федерации» (утв. Президентом РФ 07.02.2008 N Пр212) // Российская газета. 2008. № 34.

61. Супрун В.И. Ценности и социальная динамика - в кн.: Наука и ценности. Новосибирск, 1987.

62. Тюрин М.Г. Архетипы национальной правовой культуры: дис. ... канд. юрид. наук. Ростов-на-Дону, 2008.193 с.

63. Указ Президента РФ от 13.06.1996 N 884 «О доктрине развития российской науки» // Собрание законодательства РФ. 1996. № 25. Ст. 3005.

64. Указ Президента РФ от 09.10.2007 № 1351 «Об утверждении Концепции демографической политики Российской Федерации на период до 2025 года» // Собрание законодательства РФ. 2007. № 42. Ст. 5009.

65. Указ Президента РФ от 30.01.2010 № 120 «Об утверждении Доктрины продовольственной безопасности Российской Федерации» // Собрание законодательства РФ. 2010. № 5. Ст. 502.

66. Указ Президента РФ от 09.06.2010 N 690 «Об утверждении Стратегии государственной антинаркотической политики Российской Федерации до 2020 года» // Собрание законодательства РФ. 2010. № 24. Ст. 3015.

67. Указ Президента РФ от 01.06.2012 N 761 «О Национальной стратегии действий в интересах детей на $2012-2017$ годы» // Собрание законодательства РФ. 2012. № 23. Ст. 2994.

68. Федчин В.С., Степаненко А.С. Цивилизационные ценности в компаративном аспекте // Теория и практика общественного развития. 2012. № 7 / Url: http://www.teoria-practica.ru/rus/files/arhiv_zhurnala/2012/7.

69. Холодова Т.Ю. Конституционно-правовое обеспечение прав граждан на охрану здоровья и медицинскую помощь в Российской Федерации: дис.... канд. юрид. наук. Москва, 2006.

70. Чепурин В.В. Право человека на достойную жизнь и состояние его осуществления в современном российском обществе (теоретико-правовой анализ): Автореферат дис. ... канд. юрид. наук. Владимир, 2005.

71. Черных А.Е. Конституционное право граждан на охрану здоровья и проблемы его реализации в Российской Федерации: Автореферат дис. ... канд. юрид. наук. Москва, 2012. 20 с.

72. Чесноков А.А. Государственный механизм защиты прав личности в СССР и Российской Федерации: дис. ... канд. юрид. наук. Саратов, 2006. 240 с.

73. Шрага М.Х. Социальная безопасность в теории здоровья: монография / М.Х. Шрага. - Архангельск: КИРА, 2009.304 с.

74. Эбзеев Б.С. Конституция, власть и свобода в России: опыт синтетического исследования. Москва: Проспект, 2014. 336 с.

75. Эбзеев Б.С. Человек, народ, государство в конституционном строе Российской Федерации. - М.: Юрид. лит., 2005.576 с.

\section{References (transliterated):}

1. Avak'yan S.A. Globalizatsiya, obshchie konstitutsionnye tsennosti i natsional'noe regulirovanie // Sotsial'nye interesy. 2001. № 4. S. 44-47. 
2. Ardashev A.I. Konstitutsionnye osnovy obespecheniya bezopasnosti lichnosti v Rossiiskoi Federatsii: Avtoreferat dis...kand. yurid. nauk. Moskva, 2008. S. 16-17.

3. Baeva L.V. Tsennostnye osnovaniya individual'nogo bytiya: Opyt ekzistentsial'noi aksiologii: Monografiya. M.: Prometei. MPGU, 2003. 240 s. S. 7-8.

4. Balashova G.V. Pravo na okhranu zdorov'ya i meditsinskuyu pomoshch' v Rossiiskoi Federatsii: dis. ... kand. yurid. nauk. Moskva, 2000. S. 147.

5. Bevelikova N.M. Konstitutsionno-pravovye osnovy kompetentsii organov publichnoi vlasti v sfere zdravookhraneniya: dis. ... kand. yurid. nauk. Moskva, 2010. S. 25.

6. Bogomolov A.S. Opredmechivanie, tsennosti i sotsiologicheskoe poznanie // Sotsiologicheskie issledovaniya. 1975. № 2. S. 54-61.

7. Bondar' N.S. Aksiologiya sudebnogo konstitutsionalizma: konstitutsionnye tsennosti v teorii i praktike konstitutsionnogo pravosudiya. Seriya «Bibliotechka sudebnogo konstitutsionalizma». Vyp. 2. - M.: Yurist, 2013. S. 164.

8. Vlasenkova V.V. Pravo na okhranu zdorov’ya i meditsinskuyu pomoshch' v Rossiiskoi Federatsii: Avtoreferat dis. ... kand. yurid. nauk. Moskva, 2007. $21 \mathrm{~s}$.

9. Vlasova O. V. Dostoinstvo cheloveka kak nravstvenno-pravovaya tsennost' : obshcheteoreticheskoe issledovanie: Avtoref. dis. ... dokt. yurid. nauk. Saratov, 2011.

10. Domnikova L.V. Grazhdansko-pravovye sposoby realizatsii prava na okhranu zdorov'ya v Rossiiskoi Federatsii: dis.... kand. yurid.nauk. Moskva, 2006. 183 s.

11. Ereklintseva E.V. Suverenitet i demokratiya kak konstitutsionnye tsennosti sovremennoi Rossii: Avtoreferat dis. ... kand. yurid. nauk. Chelyabinsk, 2010. 25 c.

12. Zor'kin V.D. Sotsial'noe gosudarstvo v Rossii: problemy realizatsii // Sravnitel'noe konstitutsionnoe obozrenie. 2008. № 1(62). S. 49.

13. Kazantseva O.L. Konstitutsionnye tsennosti: sovremennyi opyt Rossii i zarubezhnykh stran: monografiya / O.L. Kazantseva, Yu.A. Rudt, M.N. Vorob'eva; nauch. red. E.S. Anichkin. - Barnaul: izd-vo Alt. un-ta, 2013. 137 s. (S. 16).

14. Kamenskaya N.A. Problemy formirovaniya obshchikh printsipov realizatsii konstitutsionnogo prava na okhranu zdorov'ya i meditsinskuyu pomoshch’ v Rossiiskoi Federatsii // Meditsinskoe pravo. 2011. № 4 (38). S. 20-24.

15. Karaseva I.A. Konkurentsiya konstitutsionnykh tsennostei v praktike Konstitutsionnogo Suda Rossiiskoi Federatsii i Konstitutsionnykh Sudov zarubezhnykh stran: dis. ... kand. yurid. nauk. Moskva, 2014. 244 s.

16. Kolotsei I.A. Pravo na okhranu zdorov'ya i meditsinskuyu pomoshch' kak konstitutsionnaya tsennost': Avtoreferat dis. ... kand. yurid. nauk. Sankt-Peterburg. 2010. 21 s.

17. Kruss V. I. Zdorov'e kak osnovnaya pravovaya tsennost' sovremennosti // Problemy prava. 2012. № 4 (35). S. 21-40.

18. Lapin N.I. Modernizatsiya bazovykh tsennostei rossiyan // Sotsiologicheskie issledovaniya. 1996. № 5. S.3-23.

19. Larionova I.S. Zdorov'e kak sotsial'naya tsennost': dis. ... dokt. filos. nauk. Moskva, 2004. 265 c.

20. Leont'ev D.A. Psikhologiya smysla: priroda, stroenie i dinamika smyslovoi real'nosti / D.A. Leont'ev. - M.: Smys1, $2003.487 \mathrm{~s}$.

21. Litovkina M.I. Istochniki povyshennoi opasnosti v sfere okhrany zdorov'ya: konstitutsionno-pravovoi format problemy // Natsional'naya bezopasnost' / nota bene. 2014. № 4. S.584-606

22. Mamut L.S. Gosudarstvo v tsennostnom izmerenii. - M.: Izdatel'stvo NORMA, 1998. 48 s.

23. Mastikova N.S. Tsennostnyi aspekt protsessa modernizatsii: sravnenie tsennostei rossiyan i evropeitsev: Avtoreferat dis ... kand. sotsiol. nauk. Moskva, 2015. 170 s.

24. Mikhailov S. V. Pravovye tsennosti: teoretiko-pravovoi aspekt: dis.... kand. yurid. nauk. Rostov-na-Donu, 2011. 200 s.

25. Murashko L. O. Aksiologicheskoe izmerenie protsessa pravoobrazovaniya: istoriya i sovremennost': dis.... dokt. yurid. nauk. Moskva, 2015. $378 \mathrm{~s}$

26. Nenovski N. Pravo i tsennosti. - M., Progress. 1987. S. 177.

27. Osipova M.V. Ierarkhiya yuridicheskikh tsennostei v pravovoi sisteme Rossiiskoi Federatsii: dis ... kand. yurid. nauk. Saratov, 2011. $200 \mathrm{~s}$.

28. Permilovskii M.S. Pravo na blagopriyatnuyu okruzhayushchuyu sredu kak konstitutsionnaya tsennost': Avtoreferat dis. ... kand. yurid. nauk. Kazan', 2014. 33 s.

29. Polyakov A.V. Obshchaya teoriya prava: problemy interpretatsii v kontekste kommunikativnogo podkhoda : uchebnik / A.V. Polyakov. - SPb.: S. - Peterb. gos. un-t, 2004. 260 s.

30. Roizman G.B. Ponyatie i yuridicheskaya priroda konstitutsionnykh tsennostei // Vestnik Chelyabinskogo gosudarstvennogo universiteta. 2012. № 1 (255). Pravo. Vyp. 31. S. 18-24.

31. Sergeev Yu.D., Mokhov A.A. Nenadlezhashchee vrachevanie: vozmeshchenie vreda zdorov'yu i zhizni patsienta. - M.: GEOTAR-Media. 2007.

32. Snezhko O.A. Konstitutsionnye osnovy gosudarstvennoi zashchity prav i svobod cheloveka i grazhdanina v Rossiiskoi Federatsii: dis. ... kand. yurid. nauk. Saratov, 1999. 192 c.

33. Suprun V.I. Tsennosti i sotsial'naya dinamika - v kn.: Nauka i tsennosti. Novosibirsk, 1987.

34. Tyurin M.G. Arkhetipy natsional'noi pravovoi kul'tury: dis. ... kand. yurid. nauk. Rostov-na-Donu, 2008. 193 c.

35. Fedchin V.S., Stepanenko A.S. Tsivilizatsionnye tsennosti v komparativnom aspekte // Teoriya i praktika obshchestvennogo razvitiya. 2012. № 7 / Url: http://www.teoria-practica.ru/rus/files/arhiv_zhurnala/2012/7.

36. Kholodova T.Yu. Konstitutsionno-pravovoe obespechenie prav grazhdan na okhranu zdorov'ya i meditsinskuyu pomoshch' v Rossiiskoi Federatsii: dis.... kand. yurid. nauk. Moskva, 2006.

37. Chepurin V.V. Pravo cheloveka na dostoinuyu zhizn' i sostoyanie ego osushchestvleniya v sovremennom rossiiskom obshchestve (teoretiko-pravovoi analiz): Avtoreferat dis. ... kand. yurid. nauk. Vladimir, 2005. 
DOI: $10.7256 / 1811-9018.2016 .2 .15513$

При цитировании этой статьи сноска на doi обязательна

\section{Государственные институты и правовые системы}

38. Chernykh A.E. Konstitutsionnoe pravo grazhdan na okhranu zdorov'ya i problemy ego realizatsii v Rossiiskoi Federatsii: Avtoreferat dis. ... kand. yurid. nauk. Moskva, 2012. 20 s.

39. Chesnokov A.A. Gosudarstvennyi mekhanizm zashchity prav lichnosti v SSSR i Rossiiskoi Federatsii: dis. ... kand. yurid. nauk. Saratov, 2006. $240 \mathrm{~s}$.

40. Shraga M.Kh. Sotsial'naya bezopasnost'v teorii zdorov'ya: monografiya / M.Kh. Shraga. - Arkhangel'sk: KIRA, 2009.304 s.

41. Ebzeev B.S. Konstitutsiya, vlast' i svoboda v Rossii: opyt sinteticheskogo issledovaniya. Moskva: Prospekt, 2014. 336 c.

42. Ebzeev B.S. Chelovek, narod, gosudarstvo v konstitutsionnom stroe Rossiiskoi Federatsii. - M.: Yurid. lit., 2005.576 s. 